\title{
4784 SAYILI YASA ILE GETIRILEN SOSYAL DESTEK ÖDEMESİ KARŞISINDA BANKA ZORUNLU SANDIKLARININ DURUMU
}

\author{
Yrd.Doç.Dr.Levent AKIN ${ }^{*}$
}

\section{Giriș}

2001 y1lı sonrasında yaşanan ekonomik kriz ve sebep olduğu sorunlar sorunlar, devleti çeşitli alanlarda önlem almaya itmiştir. Bu bağlamda alınan ekonomik önlemler ile çalışanların işlerine dönebilmelerine gayret sarfedilmiş, istihdam ve gelir artışı sağlayan bir dizi önlem uygulamaya konulmuştur.

$\mathrm{Bu}$ çalışmalar son y1llarda 2001 krizinin etkisinin eskisine oranla hafiflemesine katkı sağlamıştır. Buna karşın kriz yalnızca çalışanları değil, emeklileri de etkilemiş ve toplumun bu kesiminden de gelir artışı talepleri gelmiştir. Çalışma yaşamından çekildiği kabul edilen bu insanların taleplerine bir düzeyde katkı sağlamak amacıyla, 2003 yılında bir yasa çıkarılmıştır ${ }^{1} .4784$ sayılı bu yasa, söz konusu kimselere devlet tarafindan karşılıksız yardım yapılmasına imkan veren bir sosyal yardım yasasıdır ${ }^{2} . \mathrm{Bu}$ yasaya dayanılarak 506, 2925, 1479 ve 2926 sayıli yasalara tabi olarak gelir veya aylık almakta olanlara 2003 yılı boyunca sosyal destek ödemesi yapılmıştır.

\footnotetext{
* Ankara Üniversitesi Hukuk Fakültesi İş ve Sosyal Güvenlik Hukuku Ana Bilim Dalı Öğretim Üyesi.

1 Nitekim yasanın meclis plan ve bütçe komisyonundaki müzakerelerinde “...Bu düzenlemeyle yaklaşık 3 katrilyon liralık kaynağın tüketim eğilimi yüksek bir kesime aktarıldığı, bunun da durgunluk yaşayan ekonomide canlanmaya neden olacağı, tasarının bu açıdan ekonomik boyutunun da büyük önem taşıdığı..." ifade edilmiştir (TBMM Plan ve Bütçe Komisyonu 7.1.2003, Esas No. 1/341, Karar No. 5).

2 8.1.2003 tarih ve 4784 sayılı, Sosyal Sigortalar Kanunu, Tarım İşçileri Sosyal Sigortalar Kanunu, Esnaf ve Sanatkarlar ve Diğer Bağımsız Çalışanlar Sosyal Sigortalar Kurumu Kanunu ile Tarımda Kendi Adına ve Hesabına Çalışanlar Sosyal Sigortalar Kanununa Göre Gelir ve Aylık Almakta Olanlara Sosyal Destek Ödemesi Yapılması Hakkında Kanun (RG. 15.1.2003/24994 Mükerrer).
} 
4784 sayılı yasanın getirmiş olduğu imkan, Sosyal Sigortalar Kanununun geçici 20.maddesinde düzenlenen sandıklar tarafindan uygulanmamıştır. $\mathrm{Bu}$ durum sandık sigortalılarının sosyal destek ödemesinden yararlanma talebiyle konuyu yargı önüne taşımalarına sebep olmuştur. Sorun da bu noktada başlamış ve söz konusu sandık sigortalılarının 4784 sayılı yasa ile getirilen sosyal destek ödemesinden yararlanıp yararlanamayacakları önemli bir tartışma yaratmıştır.

Biz de bu çalışmamızla, konuya ilişkin gelişmeleri, verilen yargı kararlarını, sosyal güvenlik hukuku ilkeleri doğrultusunda değerlendirerek bir sonuca ulaşmaya çalışacağız.

\section{Sosyal Güvenlik Sistemimiz İçinde Sosyal Sigortalar Kanununu Geçici 20.Maddede Düzenlenen Sandık Sigortalıların Durumu}

Türk sosyal güvenlik sisteminde sosyal güvence üç temel kuruluş tarafindan sağlanır. Bunlar, Emekli Sandığı, Bağ-Kur ve Sosyal Sigortalar Kurumudur. Esası primli rejime dayalı bu kuruluşlar yanında, sistemi tamamlayan ve primsiz yürütülen sosyal yardım hizmetleri de bulunmaktadır. Türk hukukunda sosyal güvenlik sağlayan bir başka yapı da, Sosyal Sigortalar Kanununun geçici 20. maddesi çerçevesinde bankalar, sigorta-reasürans şirketleri, ticaret-sanayi odaları, borsalar ve bunların oluşturdukları birliklerin personeli için vakıf şeklinde kurulmuş zorunlu yardımlaşma sandıklarıyla, aynı yasanın 128. maddesine göre bunlara ek olarak kurulmuş munzam sandıklardır ${ }^{3} .4784$ sayılı yasa bağlamında tartışma yaratan sandiklar ise bu zorunlu olanlardır.

Sosyal güvenlik, anayasanın herkese sağlamış olduğu haklar arasındadır (m.60). İnsan Hakları Evrensel Bildirgesinde de her insanın sosyal güvenlik hakkına sahip olduğu belirtilmiştir (m.22). Anayasaya göre sosyal güvenlik, devletin görevidir ve onun tarafindan sağlanmalıdır (m.60). Sosyal devlet niteliği bunu gerektirir ${ }^{4}$. Anayasanın 60. maddesi, sosyal güvenliği sağlayacak tedbirleri alma ve teşkilâtı kurma ödevini devlete yüklemiştir

\footnotetext{
${ }^{3}$ Bkz. Kenan Tunçomăg, Sosyal Güvenlik Kavramı ve Sosyal Sigortalar, İstanbul 1991, 52, 53. Ali Bozer, Türk Hukukunda Sosyal Sigortalar Genel Bir Bakış, Ankara 1963, 32 vd. Kadir Arıcl, Sosyal Güvenlik Dersleri, Ankara 1999, 237 vd. Utkan Arasl, Sosyal Güvenlik ve Sosyal Sigortalar, C.2, Ankara 2002, 1521, 1522.

${ }^{4}$ Yüksek Mahkemeye göre: "Anayasanın 2. maddesi uyarınca Türkiye Cumhuriyeti sosyal bir hukuk devletidir. Toplumsal devlet güçsüzleri güçlüler karşısında koruyarak gerçek eşitliği ve dolayısıyla toplumsal dengeyi sağlamakla yükümlü devlet demektir. Genellikle toplum yaşamında ve özellikle sanayi toplumu olmuş ya da olma yoluna girmiş toplumların yaşamında işverenler güçlü, işçiler ise güçsüz sayılır. Anayasanın 2. maddesindeki sosyal devlet ilkesinin gerçekleştirilmesi ereği ile konulmuş bulunan 42 . ve 48. maddeler böyle bir koruma düşüncesine dayanmaktadır." 23.5.1972, Anayasa Mahkemesi Kararları Dergisi.1973, S.10, 411-412. Aynı yönde Anayasa Mahkemesi, 17.10.1972, 16/49, Anayasa Mahkemesi Kararları Dergisi 1973 S.10, 539.
} 
(m.60/II). Gerçekten de bu anayasal ödevinin sonucu olarak devlet, sosyal güvenliğin sağlanması konusunda değişik görevler üstlenmek zorundadır. $\mathrm{O}$ nedenle sosyal güvenlik, pozitif statü hakları arasında yer alır. Yani gerçekleştirilmesi için devlete aktif davranma borcu yükler 5 .

Anayasadaki bu durum karşısında devlet, her şeyden önce yasa koymak, anayasanın genel yapısına ve sosyal devlet ilkelerine uygun bir sosyal güvenlik düzeni oluşturmak zorundadır. Bunun yanında, sosyal güvenliğin sağlanması amacıyla sosyal sigortalar ve sosyal yardım teşkilatı kurmak veya kurdurmak da devletin ödevleri arasındadır ${ }^{6} .1961$ Anayasasından farklı olarak 1982 anayasasında sadece, devletin sosyal güvenliği sağlayacak teşkilatı kuracağı belirtilmiştir. 1961 anayasanda ise devletin sosyal güvenlik hakkını sağlamak için sosyal sigorta ve sosyal yardim teşkilatı kurma ve kurdurma ödevinden söz edilmiştir $(\mathrm{m} .48)^{7}$. Dolayısıyla önceki düzenlemede, şimdikinden farklı olarak, kurdurma imkanına da işaret edilmiştir.

Hemen belirtilmelidir ki, 1982 Anayasasında "kurdurma" imkanından söz edilmemiş olması, devletin artık bu imkana sahip olamadığı şeklinde değerlendirilmemektedir. Her ne kadar sosyal güvenlik kurumlarının bizzat devlet tarafından kurulması asıl olsa $\mathrm{da}^{8}$ malî kaynaklarının yetersizliği halinde devlet sosyal güvenlik örgütlerini, kurdurmak yoluna da gidebilir. Zira devlete yüklenen bu anayasal görev, yine aynı anayasayla devletin mali olanaklarıyla sınırlı tutulmuştur (m.65). Nitekim devlet bu görevini yerine getirmede yetersiz kaldığında, kapsama alamadığ güvenceye kavuşmasını sağlayabilmek için yeni imkanlar yaratmıştır.

Bunun en temel örneklerinden birini vakıf ya da dernek şeklinde örgütlenen özel yardımlaşma sandıkları oluşturur. Gerçekten de devlet, sosyal güvenlik çatısı altına alamadığı kişilerin kurmuş oldukları bu nitelikteki yapılara izin vermiş ve onları yasal düzenlemelerle güvence altına

${ }^{5}$ Bülent Tanör/Necip Yüzbaşıŏ̆lu, 1982 Anayasasına Göre Türk Anayasa Hukuku, İstanbul 2000, 178, 179. Ergun Özbudun, Türk Anayasa Hukuku, Ankara 2004, 136. Bülent Tanör, Anayasa Hukukunda Sosyal Haklar, İstanbul 1978, 13 vd. Can Tuncay/Ömer Ekmekçi, Sosyal Güvenlik Hukuku Dersleri, İstanbul 2005, 76.

${ }^{6}$ Sarper Süzek, İş Güvenliği Hukuku, Ankara 1985, 34. Ali Güzel/Ali Rıza Okur, Sosyal Güvenlik Hukuku Dersleri, İstanbul 2004, 34. Tuncay/Ekmekçi, 76.

${ }^{7}$ Nitekim Anayasa Mahkemesi de bir kararında, “...Kalkınma ve çağdaş uygarlığa ulaşma çabası içinde olan ülkemizde, sosyal güvenlik örgütlerinin tümünün Devlet tarafindan kurulamayacağı gerçeğini göz önüne alan Anayasa koyucu, 53. maddesiyle (1882/65) Devleti, iktisadî ve sosyal amaçlara ulaşıma ödevini, ancak iktisadî gelişme ile malî kaynaklarının yeterliği ölçüsü içinde yerine getirmekle yükümlü saymıştır. O halde Anayasanın bu kuralları uyarınca, Devlet, ekonomik gelişmeye ye mali kaynaklarının gücüne göre sosyal sigortalar ve sosyal yardım örgütlerini ya kendisi kurmak, ya da kaynakları yeterlik göstermiyor veya güvenliğin daha elverişli olarak sağlanacağ ${ }_{1}$ anlaşllyyorsa, kurdurmak ve onu gözetip denetlemekle ödevi altındadır...” görüşlerine yer vermiştir 25.1.1977, 1976-36/1977-2 (Anayasa Mahkemesi Kararları Dergisi, 1978, S.15, 70-71).

${ }^{8}$ Cahit Talas, Sosyal Ekonomi, Ankara 1979. 383. Süzek, 35. 
almıștır. Bu anlamda geçici 20. maddede düzenlenen sandıklar aslında, devletin sosyal güvenliği sağlama ödevini onun adına yerine getiren kuruluşlardır?. Bu yapıları nedeniyle anılan kuruluşlar, isteğe bağlı olan sandıklardan farklı olarak, üyelerinin zorunlu sosyal güvenlik kurumu niteliğindedir ${ }^{10}$. Nitekim öğretide, daha önce özel hukuk hükümlerine göre kurulmuş bulunan bu sandıkların, geçici 20.maddede düzenlenerek kamu hukuku alanına çekildikleri, bu şekilde de bir anlamda sosyal güvenlikteki dağınıklığa son verildiği kabul edilmektedir ${ }^{11}$.

\section{Sosyal Sigortalar Kanunu İle Geçici 20. Madde Kapsamındaki Sandıklar Arasındaki İliş̧ki}

Sosyal Sigortalar Kanunu yürürlüğe girmeden önce banka, sigorta, ticaret ve sanayi odaları, borsalar ile bunların birlik personelinden fikir işçisi olanların eski 3008 sayılı İş Kanununun kapsamı dışında tutulması, onları yalnızca İş Kanunundan değil, aynı zamanda salt bu kanun kapsamındakilere sağlanan sosyal güvenceden de mahrum bırakmıştır. Bu durum söz konusu çalışanları, sosyal güvencelerini sağlamak için yardımlaşma sandıkları kurmaya itmiş ${ }^{12}$, ancak 3008 sayılı İs Kanununun yerini alan 931 sayılı kanun kapsamina dahil edilmeleriyle, zorunlu olarak sosyal sigortalara tabi hale gelmişlerdir. Fakat yaratılan yeni durum onları, hem sosyal sigortalara hem de yardımlaşma sandıklarına prim ödemek zorunda bırakmıştır. Ortaya çıkan bu sorun, sandık personelini sosyal sigortalar uygulaması dışında bırakan Bakanlar Kurulu kararıyla çözülmüştür ${ }^{13}$.

Bu gelişmeyi takip eden 1965 tarih ve 506 sayılı Sosyal Sigortalar Kanununun yürürlüğüyle birlikte, dağınık haldeki sandıkların statüsü de belirlenmiştir ${ }^{14}$. 506 sayılı kanun, ilgili Bakanlar Kurulu kararındaki uygulamayı kabul etmekle birlikte, getirdiği yeni düzenlemeyle sandık personelinin eski sistemdeki kazanılmış haklarını korumuş ve sağlanacak sigorta yardımlarına bir alt sınır çizmiştir ${ }^{15}$. Bunun sonucunda kurulan ve statülerini Çalışma ve Sosyal Güvenlik Bakanlığına veren teşekkül ve sandıkların personeli, sosyal güvenceye kavuşmuş kabul edilerek Sosyal

\footnotetext{
${ }^{9}$ Y10HD.12.12.1989, 1989/5047-9068, (Yargitay Kararlar1 Dergisi, 1990/4, 560-564).

${ }^{10}$ Müjdat Şakar, Sosyal Sigortalar Uygulaması El Kitabı, İstanbul 2002, 66. Coşkun Saraç, Sosyal Sigortalar Hukukunda Kuruluş ve Üyelik Yönünden Banka, Sigorta Sandıkları, Çimento İşveren Dergisi, Kasım 2004, 38.

${ }^{11}$ Arasl, 1520. Yazara göre tümüyle özel hukuk alanında oluşturulan bu sosyal güvenlik kuruluşları, kendi statülerini korurken Devletin de vesayeti altına sokulmuş, sosyal güvenliğin sağlanması yolunda karma bir sistem ortaya çıkarılmıştır.

${ }^{12}$ Yusuf Alper, Türkiye'de Sosyal Güvenlik ve Sosyal Sigortalar, İstanbul 2003, s.49.

${ }^{13}$ Bakanlar Kurulunun 14.11.1960/5-532 sayılı kararı. Saraç, 37.

${ }^{14}$ Ali Nazım Sözer, Sosyal Sigorta İlişkisi, İzmir 1991, s.39.

${ }^{15}$ Memduh Yelekçi, Sosyal Sigortalar Kanunu Şerhi, Ankara 1991, 105. Saraç, 37. Kazanılmış hak konusunda bkz. dpn.16.
} 
Sigortalar Kanunu kapsamı dışında tutulmuştur (SSK geç.20/I). Başka bir deyişle Sosyal Sigortalar Kanunu, sandık personelini, kendi kapsamına dahil sigortalılar arasında görmediğini açıklıkla vurgulamıştır ${ }^{16}$.

Anılan hükme göre; "Bankalar, sigorta ve reasürans şirketleri, ticaret odaları, sanayi odaları, borsalar veya bunların teşkil ettikleri birlikler personelinin malullük, yaşl1lık ve ölümlerinde yardım yapmak üzere, bu kanunun yayımı tarihine kadar tesis veya dernek olarak kurulmuş bulunan sandıklar, bu kanunun yayımı tarihinden itibaren en geç altı ay içinde:

a) İlgili bulundukları banka, sigorta şirketi, reasürans şirketi, ticaret odası, sanayi odası, borsa veya bunların birliklerinin bütün personelini kapsayacak,

b) $\mathrm{Bu}$ personelin, iş kazalarıyla meslek hastalıkları, hastalık, analık, malullük, yaşlılık ve ölüm, eşlerinin analık, eş ve çocuklarının hastalık hallerinde, en az bu kanunda belirtilen yardımları sağlayacak,

c) Sandıkların statülerine tabi personelin bu madde şümulüne giren banka, sigorta şirketi, reasürans şirketi, ticaret odası, sanayi odası, borsa veya bunların birliklerinden birinden diğerine geçmesi halinde bu gibi personelin kendi sandıklarındaki müktesep haklarının da diğer ilgili sandığa veya aralarında kuracakları müşterek bir sandığa intikalini temin edecek, birer tesis haline getirildiği ve bunu tevsik eden statülerini, bu kanunun yayımı tarihinden en geç altı ay içinde Çalışma ve Sosyal Güvenlik Bakanlığına verdikleri takdirde, bu teşekküllerin ve sandıkların personeli işbu kanunun uygulanmasında sigortalı sayılmazlar..." (SSK geç.20/I).

Sosyal Sigortalar Kurumu sandık personelini yasa kapsamı dışında bırakmış olsa da, sandıkların merkezi idareden bütünüyle kopmalarına izin verilmemiştir. Nitekim yine geçici 20 maddeye göre; “...Şu kadar ki, bu sandıkların statüleri ve statü değişiklikleri Çalışma ve Sosyal Güvenlik Bakanlığınca onaylanmak suretiyle tekemmül eder. Mali durumları da Çalışma, Maliye ve Ticaret Bakanlıklarınca müşterek kontrol ve murakabe edilir. Mali durumlarının kontrol ve murakabesi sonunda alınmasına bu Bakanlıklarca müştereken lüzum gösterilecek tedbirleri, sandıklar ve ilgili bulundukları teşekküller yerine getirmekle yükümlüdür...”.

\footnotetext{
${ }^{16}$ Nitekim daha sonraki tarihlerde anılan sandıkların Sosyal Sigortalar Kurumuna devrine ilişkin bir yasa çıkarılmıştır. Ancak 11.5.1976 tarih ve 1992 sayılı bu yasanın sözü edilen devri düzenleyen 3.maddesi, Anayasa Mahkemesi tarafindan iptal edilmiştir. Kararda, bu sandıkların kuruma nazaran daha fazla sosyal sigorta yardımı sağlamış olması, kazanılmış hak olarak algılanmış ve devirlerinin bu hakkın ihlali olacağı belirtilmiştir (Resul Aslanköylü, Sosyal Sigorta Kanunu Yorumu, C.2 Ankara 2004, 2369. Arasll, 1521). Yeni hazırlanan Emeklilik Sigortası Kanunu Tasarısı Taslağında da, Sosyal Sigortalar Kanununun geçici 20.maddesi kaldırılmamıştır (m.117/1). Buna karşın, taslağın genel anlayışına uygun olarak, sandık sigortalılarının da yeni yasa kapsamına alınması planlanmaktadır. Fakat bu duruma rağmen, sandık üyelerinin taslakla getirilen düzeyi aşan yardımlardan yararlanabilmelerini sürdürebilmek için, sandıkların varlıklarını korumak kaçınılmaz görünmektedir.
} 
Dolayısıyla sandıklar, sadece kuruluş aşamasında değil, yapacakları hukuki işlem ve düzenlemelerde de denetime tabi bulunmaktadır. Devletin anayasada tanımlanmış asli görevlerinden birini onun adına yerine getiriyor olmaları ve bir çok yasada kanunla kurulmuş ayrı bir sosyal güvenlik kuruluşu olarak görülmeleri karşısında bu sandıkların, hukuki yapılarından mali durumlarına kadar genis bir alanda devlet tarafindan denetime tabi tutması doğal karşılanmalıdır ${ }^{17}$. Bunun kamu düzenini sağlayıcı bir etkisi olduğu da açıktır.

Devletin sandıklarla olan bağlantısı sadece bu uygulamalarla sınırlı değildir. Sosyal Sigortalar Kanununa eklenen bir madde ile sandıkların gerekli hallerde kurum bünyesine katılacakları düzenlenmiştir. 1994 yılında 3995 sayılı yasa ile eklenen ek 36.madde hükmüne göre; “...506 Sayılı Kanunun Geçici 20. maddesine göre, bankalar, sigorta ve reasürans şirketleri, ticaret odaları, sanayi odaları, borsalar veya bunların teşkil ettikleri birlikler personeli için kurulmuş bulunan sandıklardan; ... Bankalar Kanununa göre birleştirilen, bir başka bankaya devredilen veya bankacılık faaliyetleri sona eren bankaların personeline ait olanlar ile mali durumları üyelerinin sosyal güvenlik yardımlarını sürdürmeye elverişli olmadığı anlaşılanların yetkili organlarının ilgili mevzuat hükümlerine göre fesih ya da devir için alacakları karar üzerine, bütün aktif ve pasifleriyle birlikte Sosyal Sigortalar Kurumuna devredilmesine Bakanlar Kurulu yetkilidir... Sandıkların devri sırasında yapılacak aktüeryal hesaplamalar sonunda tespit olunacak fiili ve teknik açıklar, bu sandıkların iştirakçilerini istihdam eden kuruluşlardan tahsil edilmek üzere, Bakanlar Kurulunun karar tarihinden itibaren 3 ay içinde Hazinece Sosyal Sigortalar Kurumuna nakden ve defaten ödenir. Devredilen sandiklardan yararlanan personelin hizmet yılları ve primleri ödemek veya ödenmiş olmak suretiyle ... Sayılı Sosyal Sigortalar Kanununa göre emsallerine uygun olarak intibaklarının yapılması da dahil olmak üzere, devire ilişkin usul ve esaslar ... Bakanlığınca müştereken belirlenir...".

Bakanlar kuruluna tanınan bu yetki kapsamında çok sayıda sandık bugüne kadar Sosyal Sigortalar Kurumuna intikal etmiştir. Medeni Kanun hükümlerine göre kurulmuş bulunan ve başlangıçta sayıları 369 olan bu sandıklardan zaman içinde uygulanan devirler sonrasında 17 tane kalmıştır ${ }^{18}$ $\mathrm{Bu}$ sonucun temelinde, sandikların iyi idare edilememelerinin ve gereken düzeyde denetlenememiş olmalarının yattığı kabul edilmektedir. 2002 yılı itibariyle, bu sandıklara tâbi aktif sigortalı sayısı $72.000{ }^{\prime} \mathrm{dir}^{19}$. Ancak 8. Beş Yıllık Kalkınma Planında, rezervleri azalma gösteren ve yakın gelecekte faaliyetlerine son verebilecek yeni sandıkların olabileceği belirtilmiştir ${ }^{20}$.

\footnotetext{
${ }^{17}$ Arıcı, 224. Saraç, 38.

${ }^{18}$ Saraç, 38.

${ }^{19}$ Rakamlarla Türkiye, Temmuz 2003.

${ }^{20}$ Devlet Planlama Teşkilatı, Sekizinci Beş Yıllık Kalkınma Planı, Sosyal Güvenlik Özel
} 
Söz konusu sandıkların yatırımlarını daha ziyade bağlı oldukları bankaya yapmaları, sandıklara yönelik kararların doğrudan bankaları da etkileyebilme ihtimali ortaya çıkarmakta ve bu durum onlara yönelik uygulamaları çok daha da önemli hale getirmektedir.

Yukarıda yer verilen açıklamalardan da anlaşılacağı üzere geçici 20.maddede yer alan sandıklar, üyeleri açısından tıpk1 Sosyal Sigortalar Kurumu gibi temel bir sosyal güvenlik kurumudur. Nitekim Yargitay da bunu içtihadı birleştirme kararı ile açıklığa kavuşturmuştur. Kararda şu görüşlere yer verilmiştir: “...Geçici 20. maddede belirlenen bankalar, sigorta şirketleri, ticaret ve sanayi odaları ve borsalarla bunların oluşturdukları birliklerin yardım sandıklan yasanın hazırlanmasından önce esasen mevcut kuruluşlar olup fonksiyonlarını ifa edegelmekte idiler. 506 sayılı Yasa kendi getirdiği sosyal güvenlik sistemi içerisinde ve kendi sistemine paralel doğrultuda bu kuruluşların sandıklarını ve sandıklara bağlı personelin sosyal güvenlik haklarını bir disiplin ve güvence altına almak istemiş ve...statülerini Çalışma Bakanlığına vermelerini öngörmüştür...Geçici 20. madde, 506 sayılı Yasanın tüm sistemi içerisinde değerlendirildiğinde görüleceği üzere bu maddede sayılan sandıklar, bağlı bulundukları kuruluşların personeli hakkında yasanın düzenleme alanı içinde Sosyal Sigortalar Kurumu'nun yüklendiği görevleri, sağladığı hakları o düzeyin altına düşmemek üzere yüklenmiş sandıklar olup Geçici 20. maddede öngörülen koşullan yerine getirmelerinden itibaren görevleri ve en az yükümlülükleri yasa ile belirlenmiş ve bu alanda Sosyal Sigortalar Kurumu yerine geçen kuruluşlar niteliğini kazanmışlardır. $\mathrm{O}$ halde, 506 sayılı Yasanın 3. maddesinin I-F ve II-C bentlerinin uygulama alanı kapsamında düşünülmeleri gerektiği sonucuna varılmalıdır. Yasa koyucu da bu niteliklerini gözönünde tutmak suretiyle Geçici 20. maddenin 2. fikrasında açıkça 'Birer tesis haline getirildiği ve bunu tevsik eden statülerini bu Kanunun yayımı tarihinden en geç altı ay içinde Çalışma Bakanlığına verdikleri takdirde, bu teşekküllerin ve sandıkların personeli işbu Kanunun uygulanmasında sigortalı sayılmazlar' hükmünü getirmiştir.

Geçici 20. maddenin son fikrasında, ayrıca bu maddedeki sandıkların mevzuatına tabi olarak geçen hizmetler ile emekli sandıklarına veya malullük, yaşl1lık ve ölüm sigortalarına tabi olarak geçen hizmetlerin yazılı istek halinde 5.1.1961 tarihli, 228 sayılı Kanunun aylık bağlanmasına ilişkin esasları dairesinde birleştirilerek tahsis yapılacağı da duyurulmuştur...Geçici 20. maddedeki bu hüküm, 228 sayılı Yasanın düzenleme alanı ve ilgili bulunduğu kuruluşların niteliği dikkate alındığında yasa koyucunun Geçici 20. maddedeki sandıkları, kanunla kurulu sandık niteliğinde kabul ettiğinin ayrı bir delilini oluşturur. Geçici 20. madde kapsamına girmeyen bir yardımlaşma sandığının ise 506 sayılı yasanın 128. maddesinde söz konusu edilen bir yardımlaşma sandığı olarak kabulü icabeder. Diğer taraftan şu

ihtisas Komisyonu Raporu, 99-100, 109. 
hususta belirtilmelidir ki, belli konuların yasa ile düzenlenmesinin öngörülmesi mutlaka özel bir yasa ile düzenlenmeyi gerektirmez; konuya göre genel nitelikteki hatta konu ile ilgili olmayan herhangi bir yasa ile düzenleme de kuşkusuz yasa ile düzenleme niteliğini taşır. Bu itibarla sözcüklere mutlak ve sinırlı bir anlam verilmek suretiyle söz konusu sandıkların kuruluş kanunu bulunmadığı gerekçesinden hareket olunması, sorunun özünü ve tüm sistemini bir tarafa iterek sonuca varma anlamını taşır $\mathrm{ki}$, bu yöntem geçerli bir yorum yöntemi sayllamaz ${ }^{21}$. Hal böyle olunca, Geçici 20. maddede öngörülen sandıkların kanunla kurulu emekli sandıkları niteliğinde sayılmaları ve bunun sonucu olarak da bu sandıklardan yaşlılık aylığ 1 almakta olan kimselerin sonradan ayrıca Sosyal Sigortalar Kanunu hükümlerinden de yararlanarak yaşlılık aylığ 1 almalarına Yasanın 3/I-F, II-C ve Geçici 20. maddesinin yukarda ayrıntılı olarak açıklanan 2 ve 4 . fikraları hükümlerinin cevaz vermediğinin kabulü gerekir...(Sonuç olarak) yukarıda açıklanan nedenlerle 506 sayılı Sosyal Sigortalar Kanunun Geçici 20. maddesinde öngörülen sandıklardan yaşlılık aylığ sonradan ayrıca Sosyal Sigortalar Kanunu hükümlerinden de yararlanarak yaşlılık aylığı alamayacaklarına....karar verilmiştir." ${ }^{22}$.

İçtihadı birleştirme kararında yer verilen görüşlerden de anlaşılacağı üzere geçici 20.maddede düzenlenen sandıklar, Sosyal Sigortalar Kanununun 128. maddesinde düzenlenen yardımlaşma sandıklarından tümüyle farkl1, isteğe bağlı olmayan sandıklardır. Nitekim öğretide bazı yazarlar, 128. madde kapsamında yer alan sandıkları ihtiyari sandık, geçici 20. maddede düzenlenenleri ise zorunlu sandık olarak adlandırmıştır ${ }^{23}$.

Geçici 20. maddede yer alan sandıkların bu özelliği karşısında, kapsamına giren kişinin üyelikten vazgeçmesi veya sandığın ilgiliyi kapsam dışı bırakması söz konusu olamaz. Bu durumun konumuzu ilgilendiren yanı ise, sandık üyeliğinin başlamasından itibaren ilgilinin, Sosyal Sigortalar Kanunu açısından sigortalı sayılamıyor olmasıdır. Çalışmanın hizmet akdine dayanması da sonucu değiştirmez. Kaldı ki söz konusu durum, sosyal güvenlikte teklik ilkesinin de gereğidir. Teklik ilkesi, bir kimsenin aynı anda kanunla kurulu yalnızca bir sosyal güvenlik kuruluşuna tabi olmasını gerekli

\footnotetext{
${ }^{21}$ İçtihadı birleştirme kararına ilişkin görüşsmeler sırasında bazı üyeler 3. maddenin I/F ve II-C bentlerinin kanunla kurulu emekli sandığından söz ettiğini, bir sandığın kanunla kurulu sandık sayılabilmesi için özel bir kanunla kurulmuş olması, başka bir anlatımla kuruluş kanunu bulunması gerektiğini, kuruluş kanunu olan sandığın kanunla kurulu sandık olduğunu; Geçici 20. maddede öngörülen sandıkların kuruluş kanunlarının bulunmadığını, bu nedenle de 3 . madde uyarınca, bu sandıklardan emekli aylığı alanların 506 sayılı Yasaya göre sigortalı sayılamayacakları yolundaki yasaklama kapsamında düşünülemeyeceklerini ve bütün bunların sonucu olarak Geçici 20. maddede öngörülen sandıklardan emekli aylığg alanların ayrıca 506 sayılı Yasa'daki koşulları yerine getirdikleri takdirde bu yasa gereğince de yaşlılık aylığı alabileceklerini ileri sürmüşlerdir. Ancak bu görüş azınlıkta kalmıştır.

${ }^{22}$ Yargıtay İçtihadı Birleştirme Kurulu Kararı 9.3.1983/1-1, (RG.23.6.1983/18086).

${ }^{23}$ Saraç, 38.
} 
kılar $^{24}$. Kanunla kurulu olduğu belirtilen sosyal güvenlik kuruluşları ise zorunlu olanlardır.

Yargıtayın yukarıda belirtilen İçtihadı Birleştirme Kurulu kararında, geçici 20. madde kapsamındaki vakıflar da, kanunla kurulmuş emekli sandıklarından sayılmıştır. Kaldı ki bu değerlendirme anılan içtihattan önce öğretide de dile getirilmiştir ${ }^{25}$. Ayrıca gerek 1987 tarihli eski Sosyal Sigorta İşlemleri Yönetmeliğinin 20.maddesinde gerek 2004 tarihli yeni yönetmelikte, geçici 20. maddeye göre kurulan sandıklar, kanunla kurulu diğer sosyal güvenlik kurumları arasında sayılmıştır (SSIY m.4/r).

Başta da belirtmiş olduğumuz gibi, geçici 20.maddede yer alan sandıklar ile Sosyal Sigortalar Kanunu arasındaki ilişki, kanunun bu sandıklar için bir alt sınır oluşturması ile gerçekleşir ${ }^{26}$. Nitekim bu durum geçici 20.maddede de açıklıkla belirtilmiştir. Dolayısıyla bu ilişki dışında anılan sandıklarda geçen hizmetler, Sosyal Sigortalar Kanununa tabi geçmiş kabul edilmez. Hatta borçlanma yasalarında, sigortalıların geçici 20. maddede belirtilmiş olan sandıklarda geçen süreleri borçlanma imkanlarının bulunmadığ 1 açıkça belirtilmektedir ${ }^{2 \dagger}$. Zira bu sandıklarda geçen süreler, zorunlu sosyal güvenlik kuruluşunda geçirilmiş sayılmaktadır. Kaldı ki, 2829 sayılı Sosyal Güvenlik Kurumlarına Tabi Olarak Geçen Hizmetlerin Birleştirilmesi Hakkındaki Kanunda, haklarında hizmet birleştirmesinin uygulanabileceği kurumlar arasında, Sosyal Sigortalar Kurumundan ayrı olarak geçici 20.maddedeki sandıklar da sayılmıştır. Yani, birleştirilebilecek hizmetler sayllırken, Sosyal Sigortalar Kanununa tabi olarak geçen hizmetlere yer verilmekle yetinilmeyip, geçici 20. maddeye göre kurulan sandıklarda geçen hizmetler de ayrıca belirtilmiştir (m.2/d).

Yargıtay içtihatları da esasen yukarıda yer verilen değerlendirmelere destek olur nitelikte gelişmektedir. İçtihadı Birleştirme Kurulunun, geçici 20.madde kapsamındaki sandıkları üyeleri için zorunlu sosyal güvenlik kuruluşu sayması ile başlayan anlayış özel daire tarafından yeni kararlara da yansıtılmıștır. Buna göre, “...Bankalar, sigorta şirketleri, ticaret ve sanayi odaları gibi kuruluşlarla burada çalışanlar arasındaki hukuki ilişki temelde hizmet akdine dayansa bile bu kişiler 506 sayılı kanun kapsamında sigortalı

${ }^{24}$ Güzel/Okur, 25. Tuncay/Ekmekçi, 222. Bu kural yüksek mahkeme içtihatlarında da açıklıkla vurgulanmaktadır. Buna göre; “...davacının, her iki Sosyal Güvenlik Kurumuna tabi sigortalılığının çatıştığının saptanması durumunda ise, sosyal güvenlik sistemimizde çifte sigortalılık söz konusu olamayacağından baskın çalışmanın geçtiği Kuruma tabi sigortalılığa üstünlük tanınmalıdır...” Y10HD.10.5.2004, 1724/4114 (Yayınlanmamıştır).

${ }^{25}$ Kenan Tunçomağ, Sosyal Güvenlik Kavramı ve Sosyal Sigortalar, İstanbul, 1975, 6 O.

${ }^{26}$ Y21HD.6.4.2000, 2439/2671. Y21HD.11.3.1999, 1998-6270/1999-1668. Y21HD.2.12.1999, 8129/8735 (Arasll, 1531, 1534, 1535). Bu alt sınırın sağlık yardımları açısından da geçerli olması gerektiği konusundaki bir içtihat için bkz. Y10HD.20.6.1995, 2996/5616 (Aslanköylü, 2393, 2394).

${ }^{27}$ Bkz.1975 tarih ve 1912 sayll yasa m.7. 
olarak kabul edilemezler..."28. Bir başka kararda yer verilen görüşler ise şunlardır: "...Davacının , davalı banka mensuplarına yaptığı diş tedavisi sonunda düzenlediği makbuzlarda gelir vergisi yükümlüsü olduğu anlaş1lmaktadır. 1479 sayılı Kanunun 24/1-a maddesi hükmünce gelir vergisi yükümlüsü tabipleri Bağ-Kur sigortalısı sayılır . Ancak Dairemizin yerleşmiş uygulamasına göre, salt olarak gelir vergisi yükümlüsü olmak sigortacılık için yeterli olmayıp, temel koşul, vergi yükümlülüğünün doğumuna yol açan kendi adına ve hesabına bağımsız çalışmanın var olmasıdır. Davacının, Yapı ve Kredi Bankası tesislerindeki çalışması dışında kendi muayenehanesinde ayrı ve bağımsız çalışması varsa, yukarıda anılan yasa hükmü gereğince Bağ-Kur sigortalısı sayılır. Böyle bir durumda davacının 506 sayılı Kanunun 3/I-F maddesi gereğince Sosyal Sigortalar Kanununun geçici 20. maddesi çevresinde sigortalı sayılmasına hukuksal olarak olanak yoktur. Mahkemece, belirtilen bağımsız çalışmanın var olup olmadığı yönünde yöntemince bir araştırma ve kesin bir saptama yapılmadan davacının aynı zamanda davalı Banka Emekli Sandığı sigortalısı sayılması usul ve kanuna aykırıdır...”29.

\section{4784 Sayılı Yasa İle Sağlanan Sosyal Destek Ödemesi}

8.1.2003 tarih ve 4784 sayılı yasa, kapsamına aldığ 1 pasif sigortalılara bir sosyal yardım sağlama amacıyla çıkarılmıştır. Yasanın 1.maddesinde şu hükme yer verilmiştir. " 506 sayılı Sosyal Sigortalar Kanunu, 2925 sayılı Tarım İşçileri Sosyal Sigortalar Kanunu, 1479 sayılı Esnaf ve Sanatkârlar ve Diğer Bağımsız Çalışanlar Sosyal Sigortalar Kurumu Kanunu, 2926 sayılı Tarımda Kendi Adına ve Hesabına Çalışanlar Sosyal Sigortalar Kanununa göre gelir veya aylık almakta olanlara, 1.1.2003-31.12.2003 tarihleri arasında, genel bütçeden karşılanmak üzere, almakta oldukları aylık veya gelirlerine ilave olarak sosyal destek ödemesi yapılır. Sosyal destek ödemesinin miktarı ile usul ve esaslarını belirlemeye ve bu ödemeleri yukarıda sayılan kanunlar uyarınca aylık ve gelir tutarlarına göre aylar itibarıyla farklılaştırmaya Bakanlar Kurulu yetkilidir..."30.

Ödenen gelir ve aylıklara ilave edilecek sosyal destek ödeme miktarları ile ödemenin usul ve esasları bir Bakanlar Kurulu Kararnamesi ile düzenlenmiştir ${ }^{31}$. Anılan kararname ile, 506 ve 2925 sayılı Kanunlara göre gelir ve aylık almakta olanlara, 2003 yılında her ayın ödeme tarihlerinde 506 sayılı Kanunun ek 38. maddesine göre Ocak 2003 ayından itibaren almakta

\footnotetext{
${ }^{28}$ Y10HD.13.12.2002, 7956/9647 (Aslanköylü, 2385).

${ }^{29}$ YHGK.22.2.1995, 1994-10.881/1995-96 (Arasl, 1530).

${ }^{30}$ Yasasının genel gerekçesinde de, “ 506, 2925, 1479 ve 2926 sayılı kanunlara göre gelir veya aylık almakta olanların 2003 yılında gelir veya aylıklarının artırılmasını sağlamak amacıyla sosyal destek ödemesi adı altında ilave ödeme yapılması öngörülmekte ve bu ödemelerin miktarı ile usul ve esaslarını belirlemeye Bakanlar Kurulu yetkili kılınmaktadır..." açıklamasına yer verilmiştir

31 2003/5146 sayıl1 Bakanlar Kurulu Kararı (RG.17.01.2003/24996).
} 
oldukları gelir, aylık ve telafi edici ödemelerde yapılan artış miktarları toplamını 75 milyon TL'ye tamamlayacak şekilde sosyal destek ödemesi yapılması öngörülmüştür ${ }^{32}$. Söz konusu düzenleme, gelir ve aylıkların aylık TÜFE artış oranlarına göre yükseltilmesini öngören 506 sayılı Kanunun ek 38. maddesinde herhangi bir değişiklik yapmadığından, gelir, aylık ve telafi edici ödemelerin yükseltilmesine ilişkin işlemler önceden olduğu gibi bu madde gereğince sürdürülmüştür. Bu şekilde hesaplanan gelir, aylık ve telafi edici ödemeler toplamı, sosyal destek ödemesi ilaveli gelir veya aylık miktarını geçtiğinde, ek 38. maddenin uygulamasından doğan artışlar, toplam ödemelere yansitılmıştır.

4784 sayılı yasa ile güdülen amacı, yasanın genel gerekçesinden tespit edebilmek mümkündür. Buna göre “ 506, 2925, 1479 ve 2926 say1l kanunlara göre gelir veya aylık almakta olanların 2003 yılında gelir veya aylıklarının artırılmasını sağlamak amacıyla sosyal destek ödemesi adı altında ilave ödeme yapılması..." öngörülmüştür ${ }^{33}$. Aynı saik, yasanın plan ve bütçe komisyon raporunda da yer almaktadır: “...Bilindiği gibi ülkemizin ekonomik bakımdan en zor durumda bulunan kesimlerinden biri de emeklilerdir. 506, 2925, 1479 ve 2926 say1lı Kanunlara göre gelir veya aylık almakta olanların, her ay tüketici fiyatları indeksi değişim oranı kadar artırılan emekli aylıklarının bir bölümü asgari ücretin altında kalmış ve genel bir iyileştirme yapılması ihtiyacı ortaya çıkmıştır. Tasarı ile 506, 2925, 1479 ve 2926 sayılı Kanunlara göre gelir veya aylık almakta olanların, 2003 yılında gelir veya aylıklarının artırılması amacıyla sosyal destek ödemesi adı altında, kaynağ 1 genel bütçeden karşılanmak üzere ilave ödeme yapılması öngörülmekte ve bu ödemelerin miktarı ile usul ve esaslarını belirlemeye Bakanlar Kurulu yetkili kılınmaktadır..."

Gerek 4784 sayılı yasanın 1.maddesinin açık hükmü ve gerek gerekçede belirtilenler, anılan sosyal destek ödemesinin sadece belirtilen yasaların kapsamındaki sigortalılara uygulanacağını göstermektedir. Acaba bu ifadeden, geçici 20 .madde kapsamındaki sandık sigortalılarına da 4784 sayılı yasadan kaynaklanan sosyal destek ödemesinin yapılabileceği sonucunu çıkarmak mümkün olabilir mi ? Geçici 20. maddenin 506 sayılı Sosyal Sigortalar Kanununda düzenlenmiş olması, sandıkların da 506 sayılı yasa kapsamında değerlendirilebilmesine imkan sağlar $\mathrm{m} 1$ ?

Kanımıza göre yasal düzenlemede yer alan "506 sayıl Sosyal Sigortalar Kanununa...göre gelir veya ayllk almakta olanlara...” ifadesi, geçici 20. madde kapsamında kurulan sandıkların 4784 sayılı yasanın kapsamına alınmasına imkan tanımamaktadır. Nitekim buraya kadar ortaya konulan tablo, geçici 20.madde kapsamındaki sandık üyelerinin Sosyal

\footnotetext{
32 Sosyal Sigortalar Kurumu Başkanlığı Sigorta İşleri Genel Müdürlüğü Tahsisler Dairesi, Başkanlığı 2.1.200 tarih ve12-122.ek sayılı genelge.

33 1 yasama yıl1, 22.Dönem, S. Sayıs1 16.

34 TBMM Plan ve Bütçe Komisyonu 7.1.2003, Esas No. 1/341, Karar No. 5.
} 
Sigortalar Kanunu kapsamında değerlendirilebilmesinin mümkün bulunmadığını göstermektedir.

Dolayısıyla, geçici 20.madde kapsamındaki sandıklardan gelir ve aylık almakta olanlar, bu sandıklar aracılığıyla zorunlu sigortalılık kapsamında yer alırlar ve aynı faaliyetlerinden dolayı bir başka zorunlu sosyal güvenlik kurumu kapsamında görülemezler. Bu nedenle, 4784 sayılı yasanın 1. maddesinde yer alan düzenlemeye dayanarak sosyal destek ödemesi talep edebilmeleri mümkün görünmemektedir.

$\mathrm{Bu}$ duruma karşın, geçici 20.madde kapsamında yer alan bir banka sandığı aleyhine açılan davada yerel mahkeme, sandık sigortalılarının da 4784 sayıl1 yasa ile getirilen sosyal destek ödemesinden yararlanabileceklerine karar vermiştir. Karara gerekçe olarak da ilgili sandıkların, Sosyal Sigortalar Kurumundan daha fazla prim aldıkları, bu nedenle kurumdan aylık alanlara göre daha fazla ödeme yapmaları gerektiği belirtilmiştir. Söz konusu gerekçe ile sigortalı lehine kabul edilen dava, Yargıtay tarafından da onanarak kesinleşmiştir ${ }^{35}$.

Yukarıda da belirtildiği üzere Sosyal Sigortalar Kanunu, banka sandıkları için bir alt sınır oluşturur. Dolayısıyla sandık sigortalılarına Sosyal Sigortalar Kurumu tarafından sağlanan yardımlarından daha aşağıda yardım sağlanamaz. Nitekim yerel mahkeme de aynı düşünceyle ve bu yardımdan mahrum kalan sandık sigortalılarının Sosyal Sigortalar Kurumu seviyesinin altında kalacağı gerekçesiyle, 4784 sayılı yasa ile getirilen sosyal destek ödemesinin sandık tarafindan karşılanması gerektiğine karar vermiştir.

Oysa Sosyal Sigortalar Kurumunun sandıklar karșısında alt sınır oluşturma durumu, kendisi tarafından sağlanan sigorta yardımları ile sınırlı görülmelidir. Nitekim yasada da sandık için, “...en az bu kanunda belirtilen yardımları sağlayacak..." hükmüne yer verilmiştir (geç.20/I.b). Dolayısıyla sandık tarafından sağlanmakta olan bir sigorta yardımı, Sosyal Sigortalar Kurumuna göre daha geride kaldığında, sandıktan aradaki farkı kapatması istenebilecektir. Ancak bunun uygulamada gerçekleşme ihtimali çok zayıftır. Zira söz konusu banka sandıkları zaten Sosyal Sigortalar Kurumu düzeyinin çok üstünde yardımlar sağlamaktadır. O nedenle banka sandıklarının, salt özel bir yasa ile getirilen ve hazine tarafından karşılanacağı belirtilen bir sosyal yardımı, o özel yasanın kapsamında yer almamaları sebebiyle sigortalılarına ödememiş olmaları, sandık yardımlarının SSK seviyesinin altına düşmesi şeklinde değerlendirilemez. Kaldı ki 4784 sayılı yasa ile sağlanan sosyal destek ödemesi, Sosyal Sigortalar Kurumu tarafindan sağlanan bir sigorta yardımı niteliği de taşımaz. Çünkü 4784 sayılı yasa, getirdiği ödeneğin genel bütçeden karşılanmak üzere sağlandığını belirtmektedir. Başka bir ifade ile sosyal destek ödemesi, sosyal sigorta yardımı değil, primsiz-karşılıksız bir sosyal yardım niteliği taşımaktadır. $\mathrm{O}$

${ }^{35}$ Y10HD.13.5.2004, 1343/4295 (Yayınlanmamıştır). 
sebeple Sosyal Sigortalar Kurumu sigortalılarına verilirken sandık üyelerine verilmemesi, zaten yüksek aylık alan sandık üyelerini kuruma oranla daha aşağıda bırakmayacaktır.

Ayrıca sosyal destek ödemesinin niteliği, onun "SSK-Sandık" kıyaslamasına temel olabilmesine de engel oluşturur. Zira anılan sosyal destek ödemeleri sandık yardımlarının kıyaslandığı Sosyal Sigortalar Kurumu tarafından değil, devlet tarafından ve karşıllksız olarak, sosyal yardım şeklinde sağlanmıştır.

$\mathrm{Bu}$ durum karşısında geçici 20.maddede belirtilen banka sandıklarının, 4784 sayılı yasada kendilerine yer verilmemiş olması sebebiyle sigortalılarına söz konusu sosyal destek ödemesini yapma zorunlulukları bulunmamaktadır. Nitekim kesinleşen mahkeme kararında da sandığın sosyal destek ödemesini yapma zorunluluğu 4784 sayılı yasaya değil, SSK geçici 20.maddede yer verilen alt sınır koşuluna dayandırılmıştır. Bununla beraber yukarıda belirtmiş olduğumuz gibi, anılan ödemeleri geçici 20.maddeye dayandırabilmek de bize göre mümkün değildir.

\section{Değerlendirme}

Sosyal Sigortalar Kanununun geçici 20.maddesinde düzenlenen sandıkların, sosyal yardım şeklinde düzenlenmiş olan "sosyal destek ödemesi" yapmaları, ne 4784 sayılı yasaya ne de geçici 20. maddeye dayandırılabilir. Buna karşın konuya ilişkin olarak açılmış davalar ve kesinleşmiş yargı kararları bulunmaktadır. Dolayısıyla, mevcut durumun bir hukuksal çatıya oturtulmasında yarar vardır. $\mathrm{Bu}$ şekilde, kesinleşmiş kararları emsal gösteren yeni davalar açılması halinde, sandıklarca yapılacak yeni ödemelerin dayanağını açıklığa kavuşturabilmek de mümkün olabilir.

Kanımızca, 4784 sayılı yasa ile Sosyal Sigortalar Kurumu ve BağKur'dan aylık alanlara getirilen sosyal destek ödemesi, geçici 20.maddede yer alan sandık üyelerini muhatap almamıştır. Ancak, yargı kararları ile bu ödemenin ilgili sandıklarca yapılması gerektiğine karar verilmiştir. $\mathrm{Bu}$ durum karşısında, aleyhlerine açılan davalar sonrasında sosyal destek ödemesini yapmaları gerektiği kabul edilen sandıklar için söz konusu ödeme, bir zaruret halini almıştır. Başka bir deyişle Yargıtay kararına da konu olan hallerde ilgili sandık(lar) tarafından yapılan ödemeler, kesinleşmiş olan bir yargı kararına dayalı görülmelidir. Zira yukarıda açıklanmaya çalışılan mevcut sosyal güvenlik sistemi içindeki hukuki duruma karşın, kesinleşmiş yargı kararları hukuki anlamda tarafları bağlayıcı nitelik arzeder. Bu durum Anayasada da açıçca belirtilmiştir (Anayasa 138/IV) ${ }^{36}$. O sebeple yasal bir yükümlülük altına girmediği kabul edilse de haklarında dava açılan sandık(lar) tarafından yapılan ödemeler, 4784 ya da 506 sayılı yasalardan değil, sadece kesinleşmiş mahkeme kararına dayalı kabul edilebilir.

\footnotetext{
${ }^{36}$ Baki Kuru/Ramazan Arslan/Ejder Yılmaz, Medeni Usul Hukuku, Ankara 2004, 797, 798.
} 
$\mathrm{Bu}$ değerlendirme yeni bir sorunu da beraberinde getirmektedir. Cünkü, sandık tarafindan yapılan ödemelerin 4784 ve 506 sayılı yasalardan kaynaklanmadığı söylendiğinde, bu ödemelerin niteliğinin belirlenmesi zarureti doğmaktadır.

4784 sayılı yasa, kapsamına dahil ettiği sigortalılara, bağlı oldukları kurum tarafından bir ödeme yapılması talimatını vermiş ve hemen ardından da bunun genel bütçeden karşılanacağını dolayısıyla kurumlara ek külfet getirmeyeceğini ilan etmiştir. Yani tam anlamıyla bir sosyal yardım sağlamıştır. Yasanın bu anlayışını, 12-122.ek sayılı genelgede de görebilmek mümkündür. Genelgeyle, gelir veya aylık almakta iken evlenen k1z çocuklarına ödenecek evlenme yardımının hesaplanmasında sosyal destek ödemesi dikkate alınmamıştır. Evlenme yardımı, hak sahibinin evlendiği tarihteki (sosyal destek ödemesi hariç) gelir-aylığına göre belirlenmiş, sosyal destek ödemesi evlendiği tarihi takip eden dönem başı itibariyle diğer hak sahiplerine aktarılmıştır. Aynı genelgeyle sosyal destek ödemesi, 2829 sayılı Sosyal Güvenlik Kurumlarına Tabi Olarak Geçen Hizmetlerin Birleştirilmesi Hakkında Kanunun hesaplaşma ile ilgili hükümlerinin uygulanmasında da dikkate alınmamıştır. Ödeme dönemlerine göre peşin ödenen sosyal destek ödemeleri ise, ölüm ve durum değişikliği hallerinde geri istenmemiştir.

4784 sayıl1 yasa ile getirilen ve primli rejimi tamamlayan bu yardımların özelliği, devlet tarafından karşılıksız sağlanmasıdır. Zira primsiz rejim ${ }^{37}$ genelde, primli rejimin kapsamı dışında kalmıs ve sosyal korunmaya en fazla ihtiyaç duyanlara hizmet götürmeyi amaçlar ${ }^{38}$. Bu yönüyle, sosyal bütünleştirme işlevini üstlenerek, sosyal güvenliğin yaygınlaştırılması ilkesini yaşama geçirir ${ }^{39}$. Buna karşın primsiz rejim, sadece bazı kesimlere sosyal yardım yapmakla da yetinebilir. Nitekim 4784 sayılı yasada görülen de budur.

\footnotetext{
${ }^{37}$ Primsiz rejim yöntemleri bağlamında ayrıca bkz. Ali Nazım Sözer, Sosyal Hukuk, İzmir 1998, 23-26.

${ }^{38}$ Bu bağlamda, 8. Beș Yıllık Planda, sosyal yardım ve sosyal hizmet sağlayan kamu kurumlan ile yerel yönetimler ve gönüllü kuruluşlar arasında ișbirliği sağlamak, hedef kitlelere hazırlanan veri tabanına dayanılarak daha etkin ve hızlı hizmet sunmak, sosyal yardım ve hizmetlerden yararlanacak kesimleri objektif ölçülerle saptamak ve uygulama sonuçlarını izlemek gereği üzerinde durulmuştur. Bu amaçla sosyal yardım ve hizmetlerin programlanması, yöntemi ve koordinasyonu için yeni bir kurumsal yapılanma öngörülmüș, bu amaçla mevzuat çalışmaları hazırlık çalıșmaları başlatılmıştır (DPT VIII.Beş Yıllık Kalkınma Planı, 111, 112. Güzel/Okur, 628.). Nitekim 17.12.2004 tarihli Primsiz Ödemeler Kanunu tasarı taslağı hazırlanmıș durumdadır. Taslağın 1.maddesinde "Bu Kanunun amacı; primsiz ödemeler ve sosyal yardımlar alanında ulusal politikaların ve stratejilerin oluşturulması için ilkeleri belirlemek, yapılan primsiz ödemelerin ve sosyal yardımların kişi bazlı takibini sağlamak...sosyal güvenlik kurumları ve diğer kamu kurum ve kuruluşlarının veri tabanlarıyla bütünleşmiş bir yapı içerisinde çalışmasını sağlamak...bu alanda kullanılan kamu kaynağını objektif yararlanma ölçütlerine bağlı olarak adil ve ulaşılabilir kılınmasını sağlamak ve bu hususlara ilişkin usul ve esasları düzenlemektir." ifadesine yer verilmistir.

${ }^{39}$ Sözer, Sosyal Hukuk, 8. 9. Güzel/Okur, 628. Tuncay/Ekmekçi, 81.
} 
Yarg1 kararlarına konu olaylarda banka sandıklarınca yapılan ödemeler, 4784 sayılı yasaya, yani karşılığı devlet tarafından ödenen bir sosyal yardıma dayanmadığından, primsiz rejim kapsamında bir sosyal yardım olarak nitelendirilemez. Dolayısıyla bu ödemeyi yapan sandıklar, 4784 sayılı yasaya dayanarak hazineye müracaat imkanına sahip değildir. Başka bir deyişle anılan ödemeyi kendi varlıklarından karşılamak zorundadırlar. 4784 sayılı yasa yalnızca Sosyal Sigortalar Kurumu ve Bağ-Kur'dan aylık alanları kapsamına alarak, 5434 sayılı yasaya tabi olan ve geçici 20.madde kapsamında yer alan sigortalıları dişarıda bıraktığını açıkça göstermiştir. O nedenle, 4784 sayılı yasayla bir sosyal yardım sağlayan ve bunun karşılığını ödeyeceğini belirten hazinenin, başka bir gerekçe ile anılan ödemeyi yapmak zorunda kalanların karşılaştığı mali külfeti bu yasaya dayalı olarak gidermekle yükümlü tutulabilmesi mümkün olmamalıdır. 